\title{
Использование информационных технологий для оптимального проектирования экструзионной техники при обработке семян рапса
}

\author{
Зубкова Татьяна Михайловна \\ ФГБОУ ВО «Оренбургский государственный университет» \\ Адрес: 460018, г. Оренбург, проспект Победы, д. 13 \\ E-mail: bars87@mail.ru \\ Токарева Марина Афанасьевна \\ ФГБОУ ВО «Оренбургский государственный университет» \\ Адрес: 460018, г. Оренбург, проспект Победы, д. 13 \\ E-mail: tokareva@mail.osu.ru
}

\begin{abstract}
Описано преимущество использования экструзии для технологического процесса получения рапсового масла и жмыха с учетом требований к качеству. Приведена математическая модель процесса экструдирования с оттоком жидкой фазы. Представлены теоретические и практические исследования шнеков экструдера с различными геометрическими размерами. Приведенные результаты исследования проб образцов полученного нерафинированного рапсового масла показывают возможность его использования как качественного сырья для производства биодизельного топлива. С другой стороны, включение в рацион кормления сельскохозяйственных животных экструдированного рапса позволяет решить проблему низкой продуктивности сельскохозяйственных животных из-за неполноценного кормления по белку и аминокислотам, так как жмых является эффективным источником энергии, аминокислот и минеральных веществ. Таким образом, экструзия является фактически идеальным безотходным технологическим процессом. Представлены результаты вычислительного эксперимента для получения технико-экономических параметров процесса экструдирования по определенным значениям конструктивных, геометрических и реологических параметров малогабаритного пресс-экструдера ПЭШ-30/4. Описан процесс оптимизации шнека экструдера по методу рабочих характеристик. На основании построенных зависимостей мощности от производительности и относительной производительности по маслу от производительности экструдера, зависимости кпд от производительности построены оптимальные области при изменении шага, высоты и толщины лопастей шнека. Эти области позволили обоснованно выбрать геометрические размеры и диапазон скорости вращения шнека для обеспечения максимального кпд работы одношнекового экструдера с учетом требований к готовой продукции. Использование разработанного программного обеспечения позволяет рассчитывать технико-экономические параметры процесса и проводить оптимизацию рабочих органов экструдера в целях повышения эффективности технологического оборудования.
\end{abstract}

Ключевые слова: экструзия, одношнековый экструдер, вычислительный эксперимент, оптимизация геометрических параметров; высота, толщина, шаг лопасти шнека

\section{Введение}

В последнее время возрос интерес к получению источников энергии из растительного сырья. Рапсовое масло можно использовать как альтернативу дизельному топливу и смазочным материалам, так как оно оптимально по доступности и стоимости (Марченко \& Семенов, 2001). Жмых, который получается в результате экструдирования, используется в животноводстве для кормления сельскохозяйственных животных и птицы (Лисицын, Быкова, Давиденко, \& Минасян, 2007).
Современное шнековое экструзионное оборудование позволяют перерабатывать в большом ассортименте сырье растительного происхождения, как без оттока, так и с оттоком жидкой фазы (Мартынова, 2016).

Применение экстузионной техники позволяет осуществлять безотходный технологический процесс по производству сырья для биотоплива и кормовых добавок для животных и птицы (Пристач, Н. В \& Пристач, Л. Н., 2017; Останин, 2014; Бузоверов, 2019; Горб, 2019). 
Использование одношнекового экструдера, осуществляющего отток жидкой фазы, характеризуется низкой энергоемкостью, незначительными финансовыми затратами, возможностью механизации и автоматизации процесса получения масла и жмыха.

Таким образом, совершенствование конструкций экструзионного оборудования позволит получать качественное рапсовое масло и жмых с высоким содержанием белка, используя высокотехнологичные производственные процессы в области сельского хозяйства (Кононенко, 2017).

Экструдирование растительного сырья используемого в сельскохозяйственном назначении отражено в трудах (Албин, Майо, \& Бузман, 2019; Кононенко, 2017; Бузоверов, 2019; Брагинец, Бахчевников, \& Алферов, 2018; Исмагилов \& Малютина, 2018; Никитина, 2016; Никонов \& Бегдан, 2017; Зубкова \& Колобов, 2015а; Зубкова \& Колобов, 2015б; Зубкова, Ишакова, \& Токарева, 2014).

Использование экструзионной техники для получения масел описано (Алтайулы, Шаймерденов, \& Королькова, 2016; Заруба, Мустафаев, Калиенко, \& Андржайчак, 2015). В работах (Бессонова, Пономарева, \& Якутенок, 2017; Кальницкая и др., 2013; Корякина, 2011а; Корякина, 2011б; Пахомов, Брагинец, Алферов, Гайдаш, \& Степанова, 2016; Пахомов, Брагинец, Бахчевников, Алферов, \& Степанова, 2017; Пономарева, Филина, \& Якутенок, 2016; Василенко и др., 2018; Гукасян, Кошевой, Косачев, Схаляхов, \& Меретуков, 2019; Гукасян, Сошников, Михайлов, \& Яворская, 2019) отражены различные исследования экструдированнных продуктов и технологического процесса.

Математическое моделирование технологического процесса, расчет и оптимизация рабочих органов экструдера приведена в работах (Алексеев \& Аксенова, 2015; Артемов и др., 2019; Бакуменко, Алексеенко, \& Рубан, 2019).

Использования семян рапса для получения масла и использования его для биотоплива отмечено в трудах (Корякина, 2011а; Корякина, 2011б; Лисицын, Григорьева, \& Смирнова, 2000).

Математическое моделирование технологического процесса с оттоком жидкой фазы

Сложность математического описания технологического процесса связана прежде всего с процессами взаимодействия рабочих органов с обрабатываемым материалом. Аналитическое описание динамики процесса представляется по участкам рабочего пространства на основе проведенной декомпозиции.

Технико-экономические параметры, их связь с конструктивными и реологическими параметрами прессуемого материала осуществляется с учетом граничных условий рабочего пространства.

Рисунок 1 показывает входные и выходные параметры, которые учитывает разработанная математическая модель одношнекового экструдера с оттоком жидкой фазы и обеспечением требований к готовой продукции.

Прессующий механизм состоит из шнека, компрессионного затвора, матрицы, загрузочного устройства, шнекового цилиндра, последний компрессионный затвор и матрица образуют головку экструдера (Рис. 2). Движением материала происходит за счет его взаимодействия с рабочими органами машины.

Экструдер разбит на секции для более точного аналитического описания технологического процесса. Секцией называется участок прессующего механизма с условно постоянными параметрами процесса прессования. Математическая модель движения материалов растительного происхождения в экструдере представлена как течение псевдопластической жидкости и описана уравнением Оствальда-де Виля, связывающим напряжение сдвига $\tau_{x y}$ со скоростью сдвига $\dot{\gamma}_{x}$,

$\tau_{x y}=\mu^{\prime} \dot{\gamma}_{x}^{n}$,

где $\mu^{\prime}-$ коэффициент консистенции материала, Па $\cdot c^{n} ; n-$ индекс течения, характеризующий отклонение свойств данного материала от свойств ньютоновской жидкости.

Таким образом, задача сводится к решению системы уравнений:

$$
\begin{aligned}
& \left\{\begin{array}{l}
E_{1}\left(\sigma_{1}-\sigma_{M}\right)^{m_{0}}=H k_{\phi} \sigma_{M}^{m_{0}}, \\
k_{1}\left[A_{1}\left(\sigma_{1}-\sigma_{2}\right)^{m_{1}}+B_{1}\right]=E_{1}\left(\sigma_{1}-\sigma_{M}\right)^{m_{0}}, \\
\cdots \\
E_{i}\left(\sigma_{2 i-1}-\sigma_{2(i-1)}\right)^{m_{i}}=A_{i-1}\left(\sigma_{2 i-3}-\sigma_{2(i-1)}\right)^{m_{i-1}}+B_{i-1}, \\
k_{i} A_{i}\left(\sigma_{2 i-1}-\sigma_{2 i}\right)^{m_{i}}+B_{i}=E_{i}\left(\sigma_{2 i-1}-\sigma_{2(i-1)}\right)^{m_{i}},
\end{array}\right. \\
& \mathrm{i}=2,3, \ldots I
\end{aligned}
$$


где $I$ - число всех секций в шнековом механизме; $\mathrm{k} 1, k_{i}$ - коэффициенты оттока жидкой фазы, $m$ $=1 / n ; E_{i}-$ коэффициент, учитывающий реологические свойства материала, геометрические размеры компрессионного затвора и характер движения материала в компрессионном затворе, а также потери на местные сопротивления $\left[\mathrm{m}^{3} /\left(c \cdot \Pi^{m}\right)\right]$; $\sigma_{i}, \sigma_{1}$ - напряжения в прессуемом материале соответственно в матрице и в первой секции [Па]; $H$ - для цилиндрических каналов фильер зависит от геометрических размеров и реологических свойств материала в фильере $\left[\mathrm{M}^{3} /\left(c \cdot \Pi^{m}\right)\right] ; k_{\phi}$-число фильер в матрице; $A_{i}$ - коэффициент, учитывающий реологические свойства материала, геометрические размеры канала шнека, характер движения, отклонения формы канала шнека от прямоугольной, а также геометрические размеры полости утечек и характер движения материала в полости утечек $\left[\mathrm{M}^{3} /\left(c \cdot \Pi^{m}\right)\right]$; $B_{i}$ - коэффициент, определяющий максимально возможный расход в канале с учетом его геометрических размеров, отклонение формы канала шнека от прямоугольной, искажение формы канала $\left[\mathrm{m}^{3} / c\right]$; $\sigma_{2 i-1}, \sigma_{2 i}-$ нормальные напряжения в прессуемом материале в соответствующих секциях [Па].

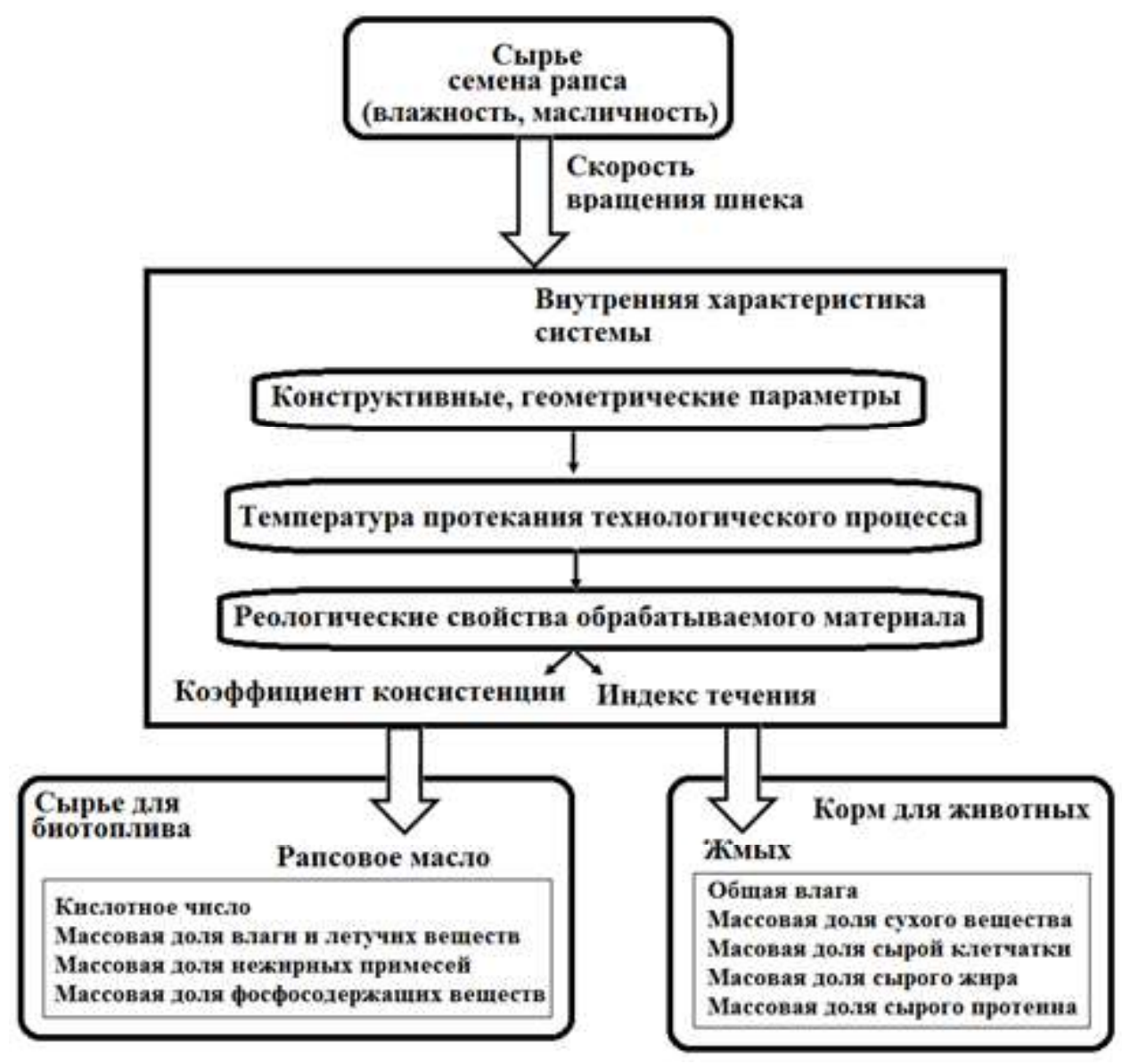

Рисунок 1. Формирование математической модели на основе системного подхода

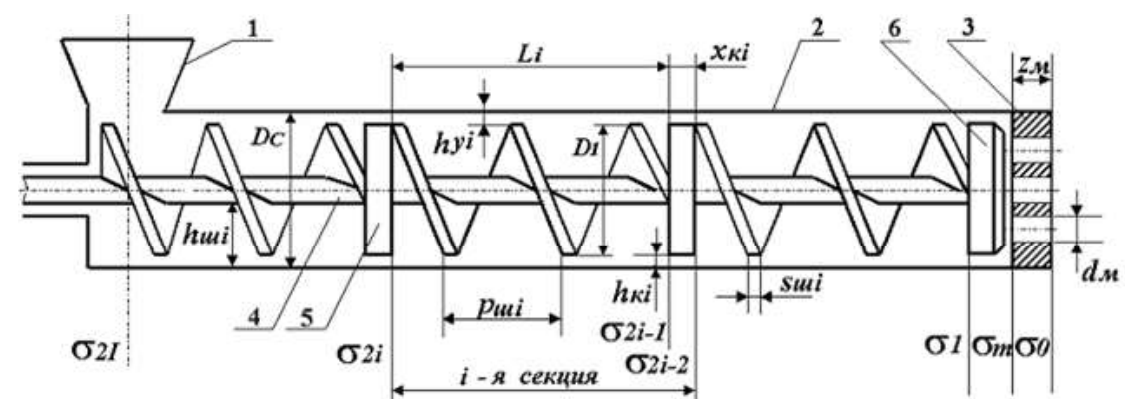

Рисунок 2. Схема прессующего механизма: 1 - загрузочное устройство; 2 - шнековый цилиндр; 3 - матрица; 4 - шнек; 5 - компрессионный затвор; 6 - головка экструдера 
Определенные в результате решения системы уравнений напряжения в прессуемом материале $\sigma_{i}, \sigma_{1}, \sigma_{i}$ позволяют рассчитать производительность экструдера по жмыху и по маслу, мощность, силу, действующую на рабочие органы, кпд.

Мощность шнекового прессующего механизма $N$ составлена из мощностей прессования материала в каждой секции $N_{i}$, то есть

$N=\sum_{i=1}^{I} N_{i}=N_{u i}+N_{y i}+N_{\kappa i}$

где $N_{u i}, N_{y i}, N_{k i}$ - соответственно мощности в канале шнека, в зазоре утечек и в компрессионном затворе $i$ - ой секции прессующего механизма.

Коэффициент полезного действия вычисляется по формуле:

$$
\eta=\frac{Q_{M}}{N} \sum_{i=1}^{I} \frac{\sigma_{2 i-1}+\sigma_{2 i-2}}{2}
$$

где $Q_{i}$ - производительность шнекового экструдера, кг/ч; $N$ - мощность, кВт.

\section{Методика экспериментального исследования}

При извлечении масла с помощью экструдера механические усилия разрушают клеточную структуру, масло вытекает, не проходя через капиллярно-пористую среду, что предохраняет его от окисления кислородом воздуха.

Экспериментальные исследования проводились на шнеках с различными геометрическими размерами (Таблица 1).

Таблица 1

Геометрические параметры шнека

\begin{tabular}{cccc}
\hline № шнека & $h_{\varnothing, M}$ & $S_{\varnothing, M}$ & $p_{\varnothing, M}$ \\
\hline 1 & 0,0110 & 0,0031 & 0,031 \\
2 & 0,0119 & 0,0071 & 0,0349 \\
3 & 0,0129 & 0,0089 & 0,039 \\
4 & 0,0139 & 0,0109 & 0,0469 \\
\hline
\end{tabular}

Качество масла оценивается по нескольким параметрам. При распаде жира в процессе хранения продукта, могут появляться жирные кислоты, содержание которых оценивается кислотным числом. В рапсовом масле необходимо осуществлять контроль содержания воды, наличие которой способствует развитию микроорганизмов, и образованию коррозии на металлических поверхностях. Сырые нерафинированные масла, получаемые экструзионным способом, могут содержать механические нежировые примеси (частицы мезги, обрывки клеточных стенок и др.). Исследование рапсового масла проводили по ГОСТ 31759-2012 ${ }^{1}$. Исследование рапсового жмыха проводили по ГОСТ 11048-95².

Наличие фосфорсодержащих веществ в рапсовом масле характеризует присутствие фосфатидов. Эти вещества обладают антиокислительной активностью. Фосфатиды гигроскопичны, поглощая воду, набухают с образованием коллоидных растворов. Последующая коагуляция их из коллоидных растворов является причиной образования в масле растительного осадка.

Влияние температуры в процессе экструдирования объединяется с эффектом резкого перепада давления во время выбрасывания продукта из экструдера. При нормальном уровне теплового воздействия-55-89 들 вонце процесса на протяжении 3-4 с (продолжительность всего процесса не более 30 c), происходит равномерная денатурация нативного белка, при этом не разрушаются первичные соединения аминокислот, что обеспечивает выпаривание нежелательной воды и образование незначительного осадка фосфатидов, а также сбережение питательной ценности рапсового масла.

\section{Результаты и их обсуждение}

Результаты исследования приведены в Таблице 2.

По результатам исследования получения рапсового масла методом экструдирования можно рекомендовать полученные образцы для технических целей. Исключением является технологический процесс при скорости вращения шнеков 23 рад/с, в этом случае массовая доля нежировых примесей превышает допустимые значения. Таким образом, рапсовое масло можно использовать в качестве сырья для производства биодизельного топлива.

Недостаточное количество в кормах белка и аминокислот зачастую обуславливает низкую продук-

\footnotetext{
1 ГОСТ 31759-2012 (2014). Масло рапсовое. Технические условия. М.: Стандартинформ.

2 ГОСТ 11048-95 (2002). Жмых рапсовый. Технические условия. М..: Стандартинформ.
} 
Таблица 2

Результаты исследования рапсового масла

\begin{tabular}{|c|c|c|c|c|c|c|}
\hline \multirow[t]{2}{*}{ Наименование показателей } & \multirow{2}{*}{$\begin{array}{c}\text { ГОСТ } \\
31759-2012 \\
\text { марка T }\end{array}$} & \multirow{2}{*}{$\begin{array}{l}\text { Номер } \\
\text { шнека }\end{array}$} & \multicolumn{4}{|c|}{ Скорость вращения шнека, рад/с } \\
\hline & & & 10 & 13 & 15 & 23 \\
\hline \multirow[t]{4}{*}{ 1. Кислотное число, мг КОН/г, не более } & 6,0 & 1 & 1,50 & 1,55 & 1,55 & 1,61 \\
\hline & & 2 & 2,37 & 2,46 & 2,23 & 2,78 \\
\hline & & 3 & 2,62 & 2,25 & 2,55 & 2,48 \\
\hline & & 4 & 1,94 & 2,08 & 1,98 & 2,35 \\
\hline \multirow{4}{*}{$\begin{array}{l}\text { 2. Перекисное число, моль ак- } \\
\text { тивного кислорода/кг }\end{array}$} & не определяется & 1 & 1,50 & 1,52 & 1,51 & 1,51 \\
\hline & & 2 & 1,51 & 1,51 & 1,52 & 1,53 \\
\hline & & 3 & 1,51 & 1,51 & 1,51 & 1,51 \\
\hline & & 4 & 1,51 & 1,50 & 1,51 & 1,50 \\
\hline \multirow{4}{*}{$\begin{array}{l}\text { 3. Массовая доля влаги и лету- } \\
\text { чих веществ \%, не более }\end{array}$} & 0,25 & 1 & 0,10 & 0,22 & 0,22 & 0,22 \\
\hline & & 2 & 0,15 & 0,31 & 0,18 & 0,10 \\
\hline & & 3 & 0,20 & 0,20 & 0,46 & 0,16 \\
\hline & & 4 & 0,10 & 0,24 & 0,23 & 0,21 \\
\hline \multirow{4}{*}{$\begin{array}{l}\text { 4. Массовая доля нежиро- } \\
\text { вых примесей \%, не более }\end{array}$} & 0,20 & 1 & 0,11 & 0,15 & 0,20 & 0,33 \\
\hline & & 2 & 0,19 & 0,11 & 0,17 & 0,29 \\
\hline & & 3 & 0,13 & 0,16 & 0,18 & 0,23 \\
\hline & & 4 & 0,20 & 0,18 & 0,18 & 0,25 \\
\hline \multirow{4}{*}{$\begin{array}{l}\text { 5. Массовая доля фосфорсодержа- } \\
\text { щих веществ в пересчете на сте- } \\
\text { ароолеолецитин \%, не более }\end{array}$} & 2,0 & 1 & 0,25 & 0,29 & 0,20 & 1,04 \\
\hline & & 2 & 0,97 & 0,83 & 1,12 & 0,54 \\
\hline & & 3 & 1,01 & 0,72 & 0,28 & 1,15 \\
\hline & & 4 & 0,36 & 0,37 & 0,63 & 0,92 \\
\hline \multirow[t]{4}{*}{ 6. Температура масла, ${ }^{\circ} \mathrm{C}$} & - & 1 & 68,00 & 65,00 & 73,00 & 58,00 \\
\hline & & 2 & 73,00 & 81,00 & 62,00 & 54,00 \\
\hline & & 3 & 82,00 & 70,00 & 88,00 & 62,00 \\
\hline & & 4 & 76,00 & 68,00 & 77,00 & 67,00 \\
\hline
\end{tabular}

тивность сельскохозяйственных животных. Жмых является эффективным источником энергии, аминокислот и минеральных веществ, и его добавление при кормлении животных позволит решить эту проблему.

Рекомендовано, чтобы содержание влаги в рапсовом жмыхе не превышало $10 \%$, в противном случае это может приводить к порче продукта. В рационе кормления сельскохозяйственных животных необходимо сухое вещество, которое представляется белками, углеводами, жирами и минеральными веществами. Для нормальной работы кишечного тракта животных необходима сырая клетчатка.

Сырой жир включает все растворимые в органических растворителях вещества: жиры, воски, смолы, свободные жирные и смоляные кислоты, эфиры этих кислот, высокомолекулярные спирты, фосфатиды, альдегиды, кетоны и др. Его энергетическая ценность выше в 2-2,5 раза углеводов.

Отличительной особенностью экструдированного продукта является высокий остаток сырого жира 
в жмыхе. Рапсовое масло содержит олеиновую кислоту, которая повышает обменную энергию корма. Это позволяет отказаться от дополнительного введения в рацион животных растительных масел.

Для полноценного питания животных необходим протеин. Под термином «сырой протеин» в комбикорме понимают общее количество азотистых соединений корма - белков, аминокислот и амидов. Протеин хорошо усваивается организмом, разлагается на необходимые аминокислоты, в этом его биологическая ценность.

Результаты исследований образцов жмыха приведены в Таблице 3.

Таблица 3

Результаты исследования рапсового жмыха

\begin{tabular}{|c|c|c|c|c|c|c|}
\hline \multirow{2}{*}{$\begin{array}{c}\text { Наименование } \\
\text { показателей }\end{array}$} & \multirow{2}{*}{$\begin{array}{c}\text { ГОСТ } \\
11048-95\end{array}$} & \multirow{2}{*}{$\begin{array}{l}\text { Номер } \\
\text { шнека }\end{array}$} & \multicolumn{4}{|c|}{ Скорость вращения шнека, рад/с } \\
\hline & & & 10 & 13 & 15 & 23 \\
\hline \multirow[t]{4}{*}{ 1. Общая влага \%, не более } & $6,0-9,0$ & 1 & 6,18 & 7,25 & 5,98 & 4,37 \\
\hline & & 2 & 4,23 & 6,98 & 6,38 & 3,92 \\
\hline & & 3 & 4,62 & 6,32 & 6,16 & 4,77 \\
\hline & & 4 & 5,13 & 5,90 & 7,47 & 3,09 \\
\hline \multirow{4}{*}{$\begin{array}{l}\text { 2. Массовая доля су- } \\
\text { хого вещества, \% }\end{array}$} & $91,0-94,0$ & 1 & 93,82 & 92,75 & 94,02 & 95,63 \\
\hline & & 2 & 95,77 & 93,02 & 93,62 & 96,08 \\
\hline & & 3 & 95,38 & 93,68 & 93,84 & 95,23 \\
\hline & & 4 & 94,87 & 93,10 & 92,53 & 96,91 \\
\hline \multirow{2}{*}{$\begin{array}{l}\text { 3. Массовая доля сы- } \\
\text { рой клетчатки, \% }\end{array}$} & 16,0 & 1 & 13,25 & 12,97 & 13,90 & 13,30 \\
\hline & & 2 & 16,50 & 15,61 & 15,36 & 14,45 \\
\hline \multirow[t]{2}{*}{ не более } & & 3 & 12,80 & 13,70 & 14,48 & 16,32 \\
\hline & & 4 & 12,60 & 16,05 & 13,70 & 15,05 \\
\hline \multirow{2}{*}{$\begin{array}{l}\text { 4. Массовая доля сы- } \\
\text { рого жира, \% }\end{array}$} & 39,0 & 1 & 38,50 & 36,41 & 37,35 & 21,29 \\
\hline & & 2 & 36,20 & 25,34 & 28,80 & 38,62 \\
\hline \multirow{2}{*}{ не более } & & 3 & 15,79 & 34,80 & 34,20 & 36,41 \\
\hline & & 4 & 24,90 & 25,70 & 27,30 & 38,71 \\
\hline \multirow{4}{*}{$\begin{array}{l}\text { 5. Массовая доля сы- } \\
\text { рого протеина, \% }\end{array}$} & 37,0 & 1 & 39,30 & 36,50 & 21,15 & 35,00 \\
\hline & & 2 & 23,14 & 22,69 & 21,90 & 27,00 \\
\hline & & 3 & 40,06 & 36,10 & 35,40 & 26,40 \\
\hline & & 4 & 23,50 & 23,60 & 36,30 & 27,70 \\
\hline \multirow[t]{4}{*}{ 6. Температура жмыха, 0С } & - & 1 & 64,00 & 67,00 & 82,00 & 63,00 \\
\hline & & 2 & 72,30 & 73,00 & 77,00 & 93,00 \\
\hline & & 3 & 61,60 & 66,00 & 68,00 & 88,00 \\
\hline & & 4 & 81,00 & 81,00 & 62,00 & 74,00 \\
\hline
\end{tabular}

Результаты анализа опытных образцов показывают, что жмых можно применять при кормлении сельскохозяйственных животных. Некоторые показателям превышают допустимые значения при скорости вращения шнеков при 10 рад/с и 23 рад/c. 


\section{Вычислительные эксперименты}

Задав определенные значения конструктивным, геометрическим и реологическим параметрам при расчете с использованием разработанного программного средства, реализующего описанную математическую модель, можно получить технико-экономические параметры процесса.

В качестве исходных данных использовали конструктивные и геометрические параметры малогабаритного пресс-экструдера ПЭШ-30/4: диаметр корпуса $D_{\mathrm{C}}=0,0552 \mathrm{~m}$; фильеры матрицы $d_{\mathrm{m}}=0,01 \mathrm{M}$; длина фильеры матрицы $z_{\mathrm{m}}=0,1 \mathrm{M}$; высота компрессионного затвора $h_{\mathrm{k}}=0,0041 \mathrm{M}$; ширина компрессионного затвора $x_{\mathrm{k}}=0,05 \mathrm{M}$; высота зазора утечек $h_{\mathrm{y}}=0,0005 \mathrm{M} ; p_{\mathrm{m}}=0,032 ;$ угол подъема винтовой лопасти $\alpha=13^{\circ}$; скорость вращения шнека $\omega=15$ рад/с; число заходов шнека равно 1. Использовали реологические параметры рапса сорта «Ратник» яровой при влажности сырья 7,49 \% (ГОСТ 10856$96^{3}$ ) и масличности $42,92 \%$ (ГОСТ 10857-644).

Результаты расчетов основных технико-экономических параметров процесса приведены на Рисунке 3.

При изменении геометрических параметров конструкции, а также скорости протекания технологического процесса технико-экономические параметры меняют свои значения.

\section{Оптимизация шнека экструдера}

Конструктивные и геометрические размеры рабочих органов экструдера влияют на качество продукта, а также на энергоемкость технологического процесса.

Так как потребительские свойства рапсового масла и жмыха при скоростях вращения шнека 13 и 15 рад/с удовлетворяют требованиям к производству биотоплива и корма, то векторную оптимизацию рабочих органов можно провести с целью получения максимального значения кпд, так как этот параметр характеризует энергоемкость машины.

Оптимизацию провели по методу рабочих характеристик.

Множество параметров $\mathrm{M}_{\mathrm{i}}, j \in[I,, n]$ (множество качеств и свойств технологического объекта) может быть представлено в виде:
$\mathrm{M}_{\mathrm{i}}=\mathrm{M}_{\mathrm{i}}\left(G_{1}, G_{2}, \ldots, G_{\mathrm{n}}\right)$,

где $G_{1}, G_{2}, \ldots, G_{\mathrm{n}}$ - геометрические, конструктивные, кинематические и другие параметры.

Программное средство предоставляет результаты оптимизации с учетом ограничений выбранных параметров.

Для проведения вычислительных экспериментов были использованы геометрические параметры малогабаритного пресс-экструдера ПЭШ-30/4 (описано выше), модернизированного для получения растительного масла и жмыха, использовали реологические параметры рапса сорта «Ратник».

Вычислительные эксперименты проводились при скоростях вращения шнека: 10, 13, 15, 20, 23 рад/с.

Были введены следующие ограничения - мощность $N<5 \mathrm{kBm}$, производительность $Q>25 \mathrm{kz} / \mathrm{u}$, кпд > 2,5, относительная производительность по маслу $k>0,3$.

Приняли толщину лопасти шнека $s_{\mathrm{m}}=0,008 \mathrm{M}$, высоту лопасти $h_{\mathrm{m}}=0,012 \mathrm{м}$, варьировали шагом $p_{\mathrm{m}}$ : 0,$03 ; 0,035 ; 0,04 ; 0,045$ в м.

Эксплуатация разработанного программного средства показана на Рисунке 4. Полученные расчетные значения приведены в Таблице 4.

На Рисунках 5 и 6 показаны зависимости мощности от производительности и относительной производительности по маслу от производительности экструдера. Вертикальными и горизонтальными линиями показаны установленные ограничения.

На Рисунке 7 показана зависимость кпд от производительности и оптимальная область с учетом заданных ограничений (на дисплее графики изображены разными цветами $0,03 \mathrm{M}$ - зеленый цвет, 0,035 - черный, 0,04 - розовый, 0,045 - желтый).

Согласно заданным ограничениям не проходит конструкция с шагом $\mathrm{p}_{\mathrm{m}}=0,45$, остальные удовлетворяют заданному условию.

Из оптимальной области видно, что максимальные значения кпд принимает при $\mathrm{p}_{\mathrm{m}}=0,035$ м при скоростях вращения шнека от 13 до 20 рад/с.

\footnotetext{
3 ГОСТ 10856-96 (2010). Семена масличные. Метод определения влажности. М.: Стандартинформ.

4 ГОСТ 10857-64 (2010). Семена масличные. Метод определения масличности. М.: Стандартинформ.
} 
Таблица 4

Расчетные технико-экономические параметры

\begin{tabular}{|c|c|c|c|c|c|}
\hline Наименование & \multicolumn{5}{|c|}{ Значения } \\
\hline Шаг винтовой лопасти шнека & \multicolumn{5}{|c|}{$0,03 \mathrm{M}$} \\
\hline Скорость вращения шнека, рад/с & 10 & 13 & 15 & 20 & 23 \\
\hline Производительность экструдера в кг/ч & 20,67 & 26,08 & 30,64 & 39,62 & 43,98 \\
\hline Кпд прессующего механизма в \% & 2,73 & 2,75 & 2,77 & 2,78 & 2,80 \\
\hline Мощность, кВт & 2,10 & 2,59 & 3,90 & 5,00 & 5,65 \\
\hline Относительная производительность по маслу & 0,27 & 0,47 & 0,5 & 0,5 & 0,49 \\
\hline Шаг винтовой лопасти шнека & \multicolumn{5}{|c|}{$0,035 \mathrm{M}$} \\
\hline Производительность экструдера в кг/ч & 21,42 & 27,69 & 31,54 & 42,34 & 47,83 \\
\hline Кпд прессующего механизма в \% & 2,82 & 2,85 & 2,89 & 2,95 & 2,97 \\
\hline Мощность, кВт & 1,9 & 2,54 & 3,60 & 4,90 & 5,20 \\
\hline Относительная производительность по маслу & 0,31 & 0,45 & 0,55 & 0,54 & 0,53 \\
\hline Шаг винтовой лопасти шнека & \multicolumn{5}{|c|}{$0,04 \mathrm{M}$} \\
\hline Производительность экструдера в кг/ч & 21,87 & 28,34 & 32,43 & 43,03 & 46,77 \\
\hline Кпд прессующего механизма в \% & 2,63 & 2,67 & 2,68 & 2,69 & 2,70 \\
\hline Мощность, кВт & 2,43 & 3,50 & 4,56 & 5,78 & 6,2 \\
\hline Относительная производительность по маслу & 0,31 & 0,45 & 0,5 & 0,49 & 0,48 \\
\hline Шаг винтовой лопасти шнека & \multicolumn{5}{|c|}{$0,045 \mathrm{M}$} \\
\hline Производительность экструдера в кг/ч & 21,28 & 27,76 & 32,04 & 41,54 & 43,80 \\
\hline Кпд прессующего механизма в \% & 2,43 & 2,46 & 2,47 & 2,48 & 2,49 \\
\hline Мощность, кВт & 2,50 & 3,95 & 4,86 & 6,10 & 6,50 \\
\hline Относительная производительность по маслу & 0,15 & 0,39 & 0,41 & 0,4 & 0,39 \\
\hline
\end{tabular}

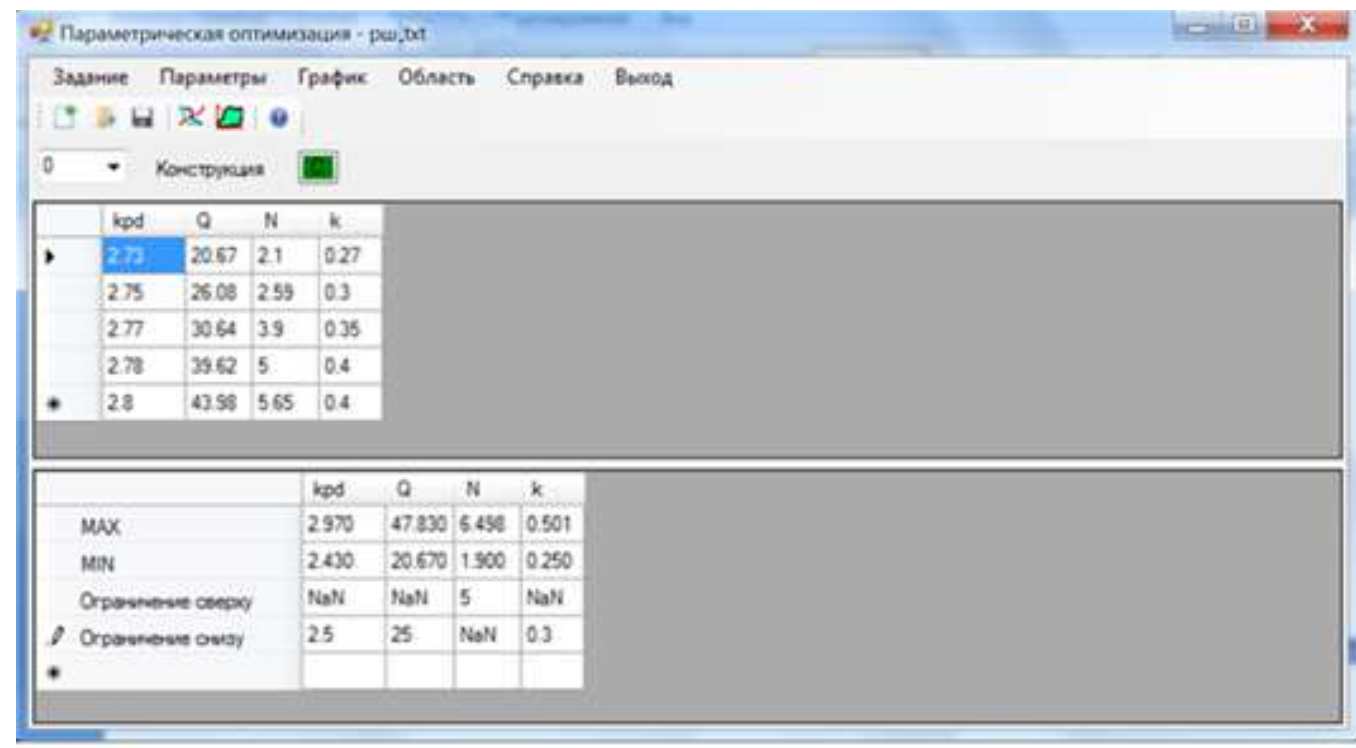

Рисунок 4. Оптимизация шнека по величине шага 


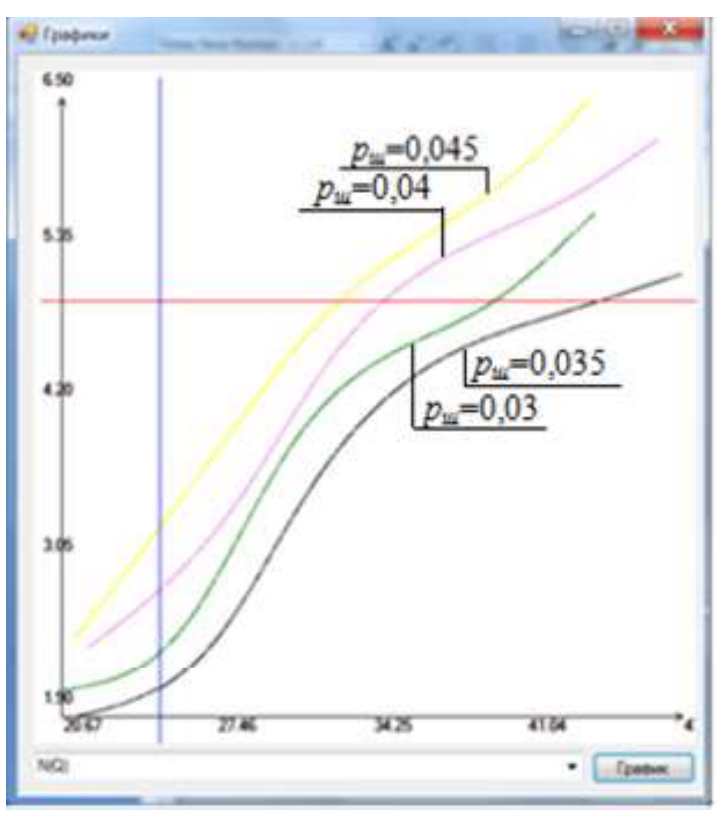

Рисунок 5. Зависимость $N=f(Q)$

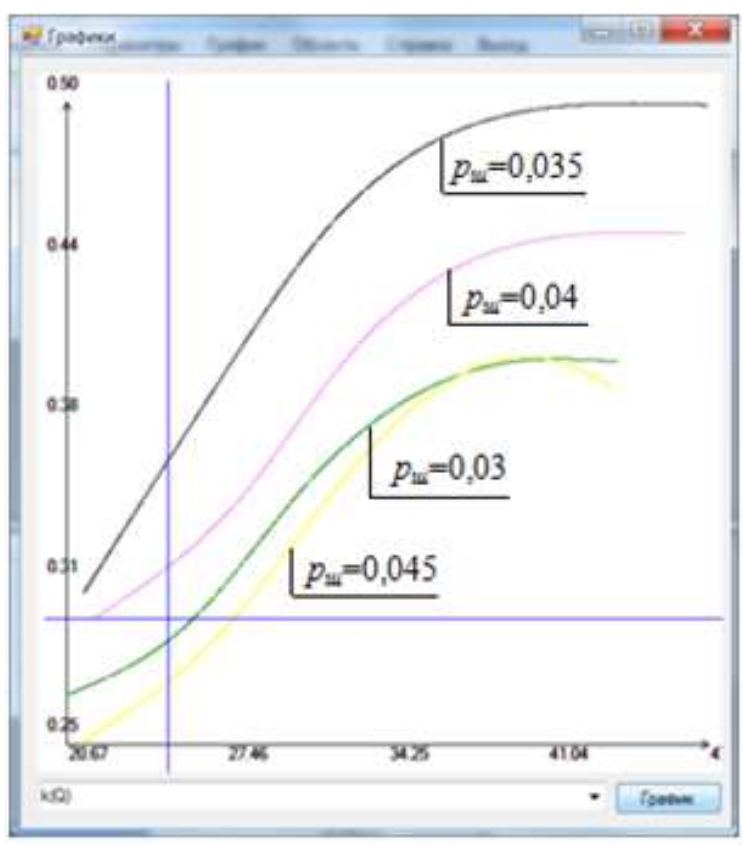

Рисунок 6. Зависимость $k=f(Q)$

Приняв шаг равным 0,035 м, варьируем толщиной лопасти шнека $s_{\text {ш: }}$ 0,003; 0,005; 0,007; 0,009 в м.

Проведя вычислительный эксперимент, получили технико-экономические результаты. Графическая интерпретация результатов аналогична рисункам 5,6 .

На рисунке 8 показана зависимость кпд от производительности и оптимальная область с учетом заданных ограничений.

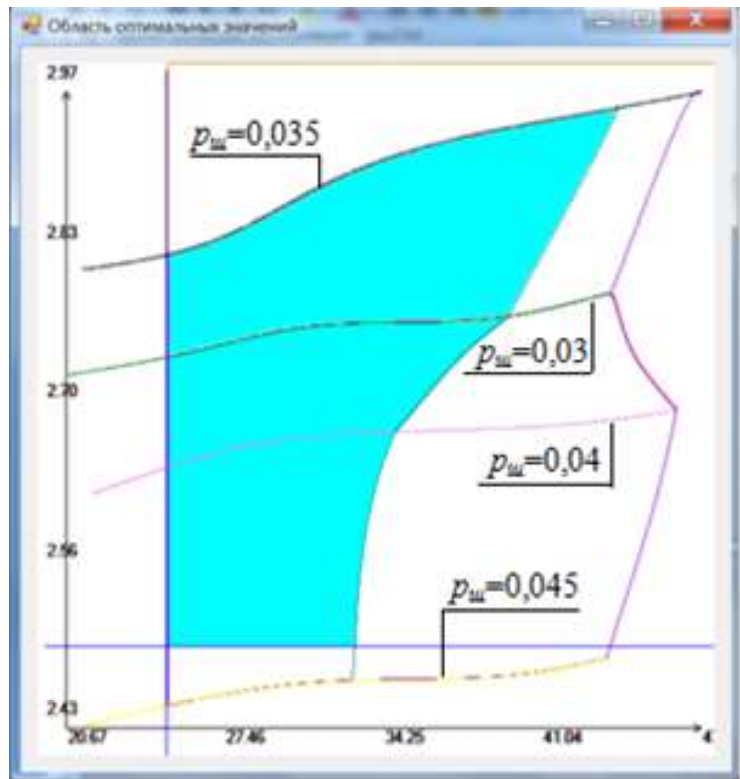

Рисунок 7. Зависимость кпд $=f(Q)$. Оптимальная область при изменении шага лопастей шнека $\mathrm{p}_{\text {ш }}$

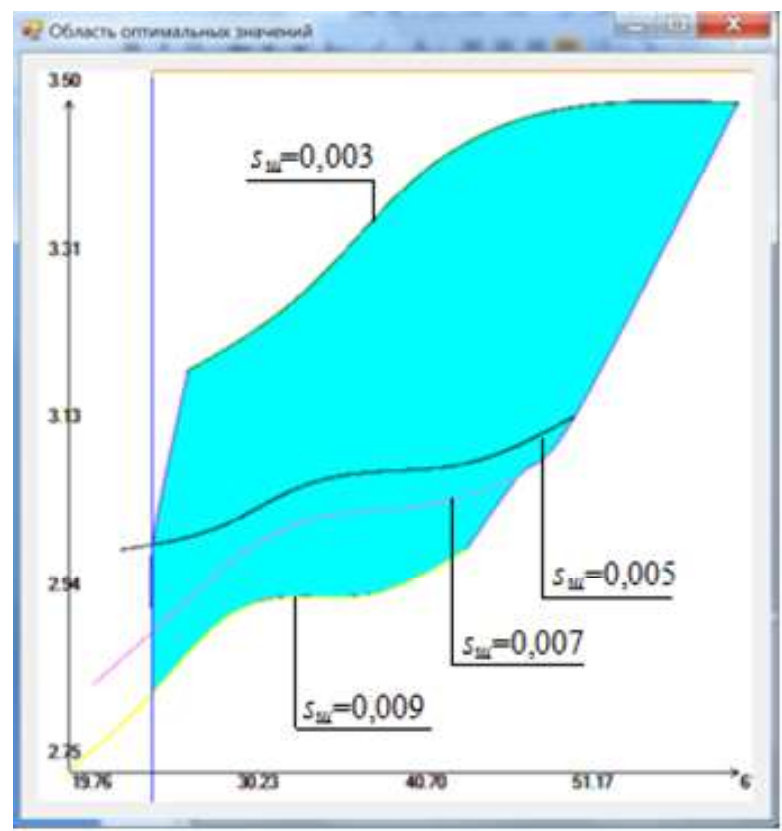

Рисунок 8. Зависимость кпд $=f(Q)$. Оптимальная область при изменении толщины лопасти шнека $s_{\text {ш }}$

Все конструкции удовлетворяют заданным ограничениям. По результатам оптимизации видно, что максимальные значения кпд принимает при $s_{\mathrm{II}}=0,003 \mathrm{M}$.

Приняв $\mathrm{p}_{\mathrm{w}}=0,035 \mathrm{м}$ и $s_{\mathrm{w}}=0,003 \mathrm{M}$, будем изменять высоту лопасти шнека $h_{\text {ш }}: 0,01 ; 0,011 ; 0,012 ; 0,013$ в м. Проведя вычислительный эксперимент, получили зависимости мощности от производительности, 


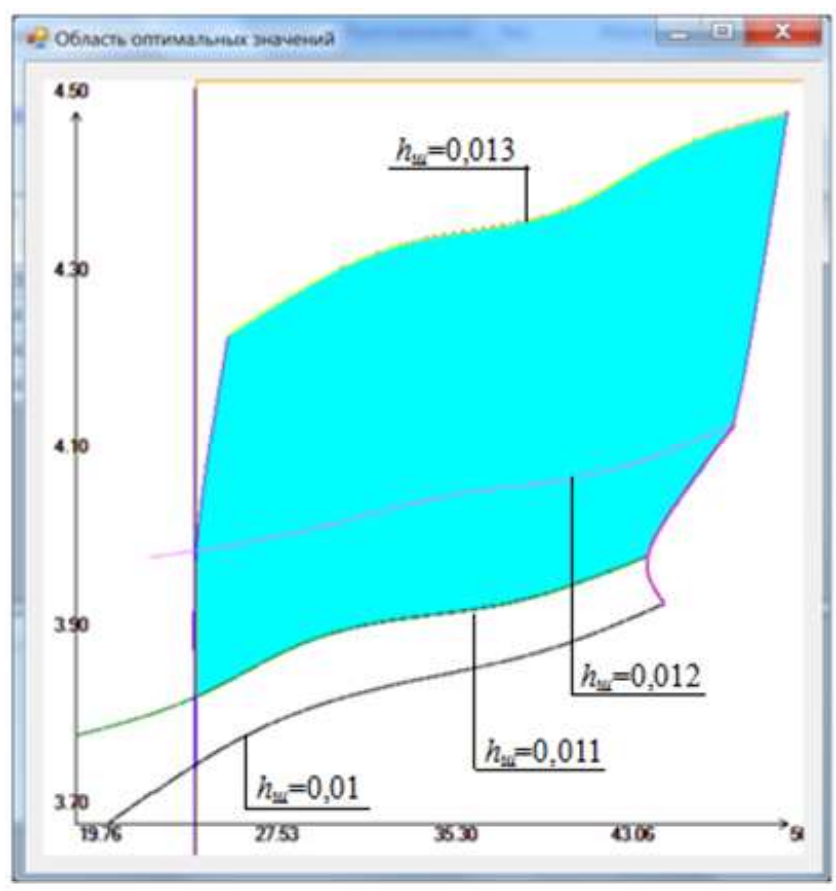

Рисунок 9. Зависимость кпд $=f(Q)$. Оптимальная область при изменении высоты лопасти шнека $h_{\mathrm{w}}$

относительной производительности по маслу от производительности экструдера (графическая интерпретация результатов аналогична рисункам 5 , 6); кпд от производительности и оптимальную область с учетом заданных ограничений (Рисунок 9).

По результатам оптимизации не удовлетворяет заданным ограничениям конструкция с высотой лопасти шнека равной $h_{ш}=0,01$. Максимальные значения кпд принимает при $h_{\mathrm{m}}=0,013$ м при всех скоростях вращения шнека.

Таким образом, по результатам оптимизации целесообразно использовать:

- $\quad$ шнек с размерами шага рш=0,035 м; толщину лопасти $s_{u}=0,003 \mathrm{M}$, высоту лопасти $h_{u}=0,013 \mathrm{M}$;

- скорость вращения шнека устанавливать в диапазоне от 13 до 20 рад/с, так как эти значения удовлетворяют все требования к производству рапсового масла в качестве сырья для биотоплива и жмыха для кормления сельскохозяйственных животных.

\section{Выводы}

Перспективным аспектом развития современного мирового топливно-энергетического производства является получение источников энергии из растительного сырья.
Поиск новых источников энергии обусловлен рядом причин: ограниченность запасов природно-ископаемых источников энергии; желание стран снизить национальную, экономическую, энергетическую зависимость, связанную с поставками энергоресурсов; стремление улучшить экологическую ситуацию.

Благодаря селекции и культивированию, рапс является ценной и перспективной культурой в общемировом производстве растительных масел.

Рапсовый жмых является высокоэнергетической протеиновой добавкой, сбалансированной по аминокислотному составу.

Экструдирование рапса обеспечивает безотходный технологический процесс.

Использование разработанного программного обеспечения позволяет рассчитывать технико-экономические параметры процесса и проводить оптимизацию рабочих органов экструдера. Таким образом, использование информационных технологий повышает эффективность технологического оборудования и качество выпускаемой продукции.

\section{Литература}

Албин, Д., Майо, К., \& Бузман, Д. (2019). Экструдирование кукурузы и использование ее в рационах молочных коров. Комбикорма, 7-8, 28-29.

Алексеев, В., \& Аксенова, О. И. (2015). Корректирование расчетов оборудования для снижения его энергоемкости на базе моделирования технологического процесса экструдирования. Техника машиностроения, 22(3), 27-37.

Алтайулы, С., Шаймерденов, Ж., \& Королькова, Н. В. (2016). Инновационная технология производства льняного масла двукратным прессованиям семян льна с экструдированием. Технологии и товароведение сельскохозяйственной продукции, 2, 28-30.

Артемов, Р. В., Арнаутов, М. В., Бочкарев, А. И., Баскакова, Ю. А., Артемов, А. В., Кокшаров, А. Е., \& Биндюков, С. В. (2019). Обоснование рациональных параметров экструдирования растительных компонентов на оборудовании малой мощности для получения комбикормов для аквакультуры. Труды ВНИРО, 176, 182-192.

Бакуменко, О. Е., Алексеенко, Е. В., \& Рубан, Н. В. (2019). Возможности использования сублимированных растительных порошков при производстве зерновых экструдированных продуктов. Хранение и переработка сельхозсырья, 1 , 116-127. 
Бессонова, М. П., Пономарева, М. А., \& Якутенок, В. А. (2017). Расчет течения степенной жидкости в одношнековом экструдере. Вестник Томского государственного университета. Математика и механика, 49, 81-104. https://doi. org/10.17223/19988621/49/8

Брагинец, С. В., Бахчевников, О. Н., \& Алферов, А. С. (2018). Экструдирование смеси зерновых и зеленых кормов. Сельский механизатор, 2, 28-29.

Бузоверов, С. Ю. (2019). Использование процесса экструдирования для повышения качества зерновых продуктов. Международный журнал гуманитарных и естественных наук, 8, 9-12.

Василенко, В. Н., Фролова, Л. Н., Дерканосова, А. А., Михайлова, Н. А., Щепкина, А. А., \& Давыдов, А. М. (2018). Математическое обеспечение процесса экструдирования аномально-вязких сред методами планирования эксперимента. Вестник Воронежского государственного университета инженерных технологий, 80(3), 37-42. https:// doi.org/10.20914/2310-1202-2018-3-37-42

Горб, С. С. (2019). Технологический процесс экструдирования и анализ современных конструкций пресс-экструдеров для приготовления концентрированных кормов в животноводстве. Научная жизнь, 2, 98-103.

Гукасян, А. В., Кошевой, Е. П., Косачев, В. С., Схаляхов, А. А., \& Меретуков, 3. А. (2019). Моделирование реологических зависимостей процесса экструдирования масличного материала. Новые технологии, 3, 41-50. https://doi. org/10.24411/2072-0920-2019-10304

Гукасян, А. В., Сошников, В. К., Михайлов, Е. А., \& Яворская, А. В. (2019). Модель кинетики отжима при экструдировании масличных материалов // Известия высших учебных заведений. Пищевая технология, 1, 65-69.

Заруба, А. С., Мустафаев, С. К., Калиенко, Е. А., \& Андржайчак, А. А. (2015). Изучение качества льняных масла и жмыха, полученных по новой технологии двукратного прессования семян льна с экструдированием. Электронный сетевой политематический журнал «Научные труды КубГТУ», 2, 69-78.

Зубкова, Т. М., \& Колобов, А. Н. (2015а). Влияние экструдирования семян рапса на качество готовой продукции. Вестник Российской академии сельскохозяйственных наук, 5, 11-14.

Зубкова, Т. М., \& Колобов, А. Н. (2015б). Использование программного обеспечения для определения и прогнозирования показателей качества экструдированной продукции. Программные продукты и системы, 3, 123-129. https://doi.org/10.15827/0236-235X.111.123-128

Зубкова, Т. М., Ишакова, Е. Н., \& Токарева, М. А. (2014). Разработка программного обеспечения визуализации процедуры многомерной оптимизации функциональных показателей технологического процесса. Научно-технический вестник информационных технологий, механики и оптики СПбГУ ИТМО, 3, 156-162.

Исмагилов, Р. Р., \& Малютина, К. В. (2018). Вязкость водного экстракта и содержание питательных веществ в зерне озимой ржи при экструдировании. Известия Оренбургского государственного аграрного университета, 5, 74-77.

Кальницкая, О. И., Карелина, Е. А., Семенов, Г. В., Бабин, Ю. В., Тагиров, А. М., \& Михайлов, И. В. (2013). Оценка качества и безопасности белкового гидролизата как основы для получения экструдированных продуктов. Хранение и переработка сельхозсырья, 1, 38-40.

Кононенко, С. И. (2017). Экструдирование кормов - путь к увеличению рентабельности животноводства. Эффективное животноводство, 1 , 32-33.

Корякина, М. А. (2011a). Оптимизация параметров шнека экструдера для получения рапсового масла. Известия Оренбургского государственного аграрного университета, 3, 71-74.

Корякина, М. А. (2011б). Повышение эффективности работы одношнекового экструдера на основе структурно-параметрического синтеза для прессования семян рапса (Дисс. канд. техн. наук). Оренбург: ГОУ ВПО «Оренбургский государственный университет».

Лисицын, А. Н., Быкова, С. Ф., Давиденко, Е. К., \& Минасян, Н. М. (2007). Биологические особенности сортов рапса и физиологические ценности жмыхов и шротов. Масложировая промышленность, 6, 18-20.

Лисицын, А. Н., Григорьева, В. Н., \& Смирнова, Е. Е. (2000). Возможные пути использования семян рапса. Масложировая промышленность, 4, 14-15.

Мартынова, Д. В. (2016). Оптимизация процесса экструдирования белково-клетчатко-крахмалосодержащего сырья. Интеллект. Инновации. Инвестиции, 3, 151-156.

Марченко, А. П., \& Семенов, В. Г. Альтернативное биотопливо на основе производных рапсового масла. Химия и технология топлив и масел, 3 , 31-32.

Никитина, В. Ю. (2016). Экструдирование соевых бобов. Новая наука: Проблемы и перспективы, 6-2, 209-211.

Никонов, О. И., \& Бегдан, Н. В. (2017). Двухстадийное экстрагирование в технологических схемах переработки масличного сырья. Альманах мировой науки, 1-1, 62-65.

Останин, Л. М. (2014). Рапсовое масло - сырье для производства биотоплива. Вестник Казанского технологического университета, 17(2), 227-228. 
Пахомов, В. И., Брагинец, С. В., Алферов, А. С., Гайдаш, М. В., \& Степанова, Ю. В. (2016). Исследования процесса экструдирования смеси зерновых концентратов с измельченной зеленой массой бобовых трав. Вестник Донского государственного технического университета, 16(2), 154-159. https://doi.org/10.12737/19684

Пахомов, В. И., Брагинец, С. В., Бахчевников, О. Н., Алферов, А. С., \& Степанова, Ю. В. (2017). Результаты экспериментальных исследований процесса совместного экструдирования фуражного зерна и зеленой массы люцерны. Вестник
Курской государственной сельскохозяйственной академии, 9, 45-48.

Пономарева, М. А., Филина, М. П., \& Якутенок, В. А. (2016). Циркуляционное течение высоковязкой неньютоновской жидкости в канале одношнекового экструдера. Вестник Томского государственного университета. Математика и механика, 2, 97-107. https://doi. org/10.17223/19988621/40/10

Пристач, Н. В., \& Пристач, Л. Н. (2017). Жмых рапсовый в кормлении скота. Сельскохозяйственные вести, 1, 8-9. 


\title{
The Use of The Information Technology for the Optimal Design of Extrusion Technology in the Processing of Rapeseeds
}

\author{
Tatyana M. Zubkova \\ Orenburg State University \\ 13, Avenue Pobeda, Orenburg, 460018, Russian Federation \\ E-mail:bars87@mail.ru \\ Marina A. Tokareva \\ Orenburg State University \\ 13, Avenue Pobeda, Orenburg, 460018, Russian Federation \\ E-mail: tokareva@mail.osu.ru
}

\begin{abstract}
The article describes the advantage of extrusion using for the technological process of high-quality rapeseed oil and oilcake. Mathematical modeling of the technological process with the outflow of the liquid phase has been considered. Theoretical and practical studies of extruder screws with various geometrical dimensions have been presented. The results of the study of the obtained unrefined rapeseed oil samples show the possibility of its use as a quality raw material for the production of biodiesel fuel. On the other hand, the extruded rapeseed in the diet of farm animal helps to solve the problem of low productivity of farm animals due to inadequate feeding in protein and amino acids, since oilcake is an effective source of energy, amino acids and minerals. The results of the computational experiment to obtain the technical and economical parameters of the extrusion process according to certain values of the design, geometric and rheological parameters of the small-sized press-extruder PESH-30/4 have been presented. The process of optimization of the extruder screw according to the performance method has been described. On the basis of the constructed dependences of power on productivity and relative productivity, the optimal regions were constructed when changing the pitch, thickness and height of the screw blades. These areas made it possible to reasonably select the geometrical dimensions and the range of the screw rotation speed to ensure the maximum efficiency of the singlescrew extruder operation at high quality indicators of rapeseed oil for biofuel and oilcake for feeding farm animals. Thus, the extrusion is virtually an ideal waste-free process. The use of the developed software makes it possible to calculate the technical and economic parameters of the process and to optimize the working bodies of the extruder in order to increase the efficiency of the technological equipment.
\end{abstract}

Keywords: extrusion, single-screw extruder, mathematical modeling, computational experiment, optimization of the geometric parameters of the screw. height, thickness, pitch of the auger blade

\section{References}

Albin, D., Maio, K., \& Buzman, D. (2019). Ekstrudirovanie kukuruzy $\mathrm{i}$ ispol'zovanie ee $\mathrm{v}$ ratsionakh molochnykh korov [Extrusion of corn and its use in the diets of dairy cows]. Kombikorma [Compound feed], 7-8, 28-29.

Alekseev, V., \& Aksenova, O. I. (2015). Korrektirovanie raschetov oborudovaniya dlya snizheniya ego energoemkosti na baze modelirovaniya tekhnologicheskogo protsessa ekstrudirovaniya [Correction of calculations of equipment to reduce its energy consumption on the basis of modeling the technological process of extrusion]. Tekhnika mashinostroeniya [Engineering], 22(3), 27-37.
Altaiuly, S., Shaimerdenov, Zh., \& Korol'kova, N. V. (2016). Innovatsionnaya tekhnologiya proizvodstva l'nyanogo masla dvukratnym pressovaniyam semyan l'na s ekstrudirovaniem [Innovative technology for the production of flaxseed oil by double pressing of flax seeds with extrusion]. Tekhnologii $i$ tovarovedenie sel'skokhozyaistvennoi produktsii [Technologies and commodity science of agricultural products], 2, 28-30.

Artemov, R. V., Arnautov, M. V., Bochkarev, A. I., Baskakova, Yu. A., Artemov, A. V., Koksharov, A. E., \& Bindyukov, S. V. (2019). Obosnovanie ratsional'nykh parametrov ekstrudirovaniya rastitel'nykh komponentov na oborudovanii maloi moshchnosti dlya polucheniya kombikormov dlya ak- 
vakul'tury [Substantiation of rational parameters of extrusion of plant components on low-power equipment for obtaining compound feed for aquaculture]. Trudy VNIRO [Proceedings of the AllRussian Scientific Research Institute of Fisheries and Oceanography], 176, 182-192.

Bakumenko, O. E., Alekseenko, E. V., \& Ruban, N. V. (2019). Vozmozhnosti ispol'zovaniya sublimirovannykh rastitel'nykh poroshkov pri proizvodstve zernovykh ekstrudirovannykh produktov [Possibilities of using freeze-dried plant powders in the production of grain extruded products]. Khranenie i pererabotka sel'khozsyr'ya [Storage and processing of Farm Products], 1, 116-127.

Bessonova, M. P., Ponomareva, M. A., \& Yakutenok, V. A. (2017). Raschet techeniya stepennoi zhidkosti v odnoshnekovom ekstrudere [Calculation of the flow of a power-law fluid in a single-screw extruder]. Vestnik Tomskogo gosudarstvennogo universiteta. Matematika i mekhanika [Bulletin of the Tomsk State University. Mathematics and Mechanics], 49, 81-104. https://doi.org/10.17223/19988621/49/8

Braginets, S. V., Bakhchevnikov, O. N., \& Alferov, A. S. (2018). Ekstrudirovanie smesi zernovykh i zelenykh kormov [Extruding a mixture of grain and green fodder]. Sel'skii mekhanizator [Rural mechanic], 2, 28-29.

Buzoverov, S. Yu. (2019). Ispol'zovanie protsessa ekstrudirovaniya dlya povysheniya kachestva zernovykh produktov [Using the extrusion process to improve the quality of grain products]. Mezhdunarodnyi zhurnal gumanitarnykh i estestvennykh nauk [International Journal of Humanities and Natural Sciences], 8, 9-12.

Gorb, S. S. (2019). Tekhnologicheskii protsess ekstrudirovaniya i analiz sovremennykh konstruktsii press-ekstruderov dlya prigotovleniya kontsentrirovannykh kormov $\mathrm{V}$ zhivotnovodstve [Technological process of extrusion and analysis of modern designs of press-extruders for the preparation of concentrated feed in animal husbandry]. Nauchnaya zhizn' [Scientific life], 2, 98-103.

Gukasyan, A. V., Koshevoi, E. P., Kosachev, V. S., Skhalyakhov, A. A., \& Meretukov, Z. A. (2019). Modelirovanie reologicheskikh zavisimostei protsessa ekstrudirovaniya maslichnogo materiala [Modeling of rheological dependencies of the process of extruding oilseed material]. Novye tekhnologii [New technologies], 3, 41-50. https://doi. org/10.24411/2072-0920-2019-10304

Gukasyan, A. V., Soshnikov, V. K., Mikhailov, E. A., \& Yavorskaya, A. V. (2019). Model' kinetiki otzhima pri ekstrudirovanii maslichnykh materialov // Izvestiya vysshikh uchebnykh zavedenii [Model extraction kinetics by extruding oleaginous materials]. Pishchevaya tekhnologiya [Proceedings of the higher educational institutions. Food technology], 1, 65-69.

Ismagilov, R. R., \& Malyutina, K. V. (2018). Vyazkost' vodnogo ekstrakta i soderzhanie pitatel'nykh veshchestv $\mathrm{v}$ zerne ozimoi rzhi pri ekstrudirovanii [The viscosity of the aqueous extract and the content of nutrients in the grain of winter rye during extrusion]. Izvestiya Orenburgskogo gosudarstvennogo agrarnogo universiteta [Bulletin of the Orenburg State Agrarian University], 5, 74-77.

Kal'nitskaya, O. I., Karelina, E. A., Semenov, G. V., Babin, Yu. V., Tagirov, A. M., \& Mikhailov, I. V. (2013). Otsenka kachestva i bezopasnosti belkovogo gidrolizata kak osnovy dlya polucheniya ekstrudirovannykh produktov [Assessment of the quality and safety of protein hydrolyzate as a basis for extruded products]. Khranenie i pererabotka sel'khozsyr'ya [Storage and processing of agricultural raw materials], 1, 38-40.

Kononenko, S. I. (2017). Ekstrudirovanie kormov - put' $\mathrm{k}$ uvelicheniyu rentabel'nosti zhivotnovodstva [Extrusion of feed - the way to increase the profitability of animal husbandry]. Effektivnoe zhivotnovodstvo [Effective animal husbandry], 1, 32-33.

Koryakina, M. A. (2011a). Optimizatsiya parametrov shneka ekstrudera dlya polucheniya rapsovogo masla [Optimization of the parameters of the extruder screw for rapeseed oil production]. Izvestiya Orenburgskogo gosudarstvennogo agrarnogo universiteta [Bulletin of the Orenburg State Agrarian University], 3, 71-74.

Koryakina, M. A. (2011b). Povyshenie effektivnosti raboty odnoshnekovogo ekstrudera na osnove strukturno-parametricheskogo sinteza dlya pressovaniya semyan rapsa (Diss. kand. tekhn. nauk) [Improving the efficiency of a single-screw extruder based on structural-parametric synthesis for pressing rapeseeds (Master's thesis)]. Orenburg: GOU VPO «Orenburgskii gosudarstvennyi universitet».

Lisitsyn, A. N., Bykova, S. F., Davidenko, E. K., \& Minasyan, N. M. (2007). Biologicheskie osobennosti sortov rapsa i fiziologicheskie tsennosti zhmykhov i shrotov [Biological characteristics of rapeseed varieties and physiological values of oilcakes and meal]. Maslozhirovaya promyshlennost' [Oil and fat industry], 6, 18-20.

Lisitsyn, A. N., Grigor'eva, V. N., \& Smirnova, E. E. (2000). Vozmozhnye puti ispol'zovaniya semyan rapsa [Possible ways of using rape seeds]. Maslozhirovaya promyshlennost' [Oil and fat industry], 4, 14-15.

Marchenko, A. P., \& Semenov, V. G. Al'ternativnoe biotoplivo na osnove proizvodnykh rapsovogo masla [Alternative biofuel based on rapeseed oil derivatives]. Khimiya $i$ tekhnologiya topliv $i$ masel [Chemistry and technology of fuels and oils], 3, 31-32. 
Martynova, D. V. (2016). Optimizatsiya protsessa ekstrudirovaniya belkovo-kletchatko-krakhmalosoderzhashchego syr'ya [Optimization of the process of extruding protein-fiber-starch-containing raw materials]. Intellekt. Innovatsii. Investitsii [Intellect. Innovation. Investments], 3, 151-156.

Nikitina, V. Yu. (2016). Ekstrudirovanie soevykh bobov [Soybean extrusion]. Novaya nauka: Problemy i perspektivy [New Science: Problems and Prospects], 6-2, 209-211.

Nikonov, O. I., \& Begdan, N. V. (2017). Dvukhstadiinoe ekstragirovanie $\mathrm{v}$ tekhnologicheskikh skhemakh pererabotki maslichnogo syr'ya [Two-stage extraction in technological schemes for processing oilseed raw materials]. Al'manakh mirovoi nauki [Almanac of world science], 1-1, 62-65.

Ostanin, L. M. (2014). Rapsovoe maslo - syr'e dlya proizvodstva biotopliva [Rapeseed oil is a raw material for biofuel production]. Vestnik Kazanskogo tekhnologicheskogo universiteta [Bulletin of Kazan Technological University], 17(2), 227-228.

Pakhomov, V. I., Braginets, S. V., Alferov, A. S., Gaidash, M. V., \& Stepanova, Yu. V. (2016). Issledovaniya protsessa ekstrudirovaniya smesi zernovykh kontsentratov s izmel'chennoi zelenoi massoi bobovykh trav [Investigations of the process of extruding a mixture of grain concentrates with crushed green mass of legumes]. Vestnik Donskogo gosudarstvennogo tekhnicheskogo universiteta [Bulletin of the Don State Technical University], 16(2), 154-159. https://doi.org/10.12737/19684

Pakhomov, V. I., Braginets, S. V., Bakhchevnikov, O. N., Alferov, A. S., \& Stepanova, Yu. V. (2017). Rezul'taty eksperimental'nykh issledovanii protsessa sovmestnogo ekstrudirovaniya furazhnogo zerna i zelenoi massy lyutserny [Results of experimental studies of the process of joint extrusion of feed grain and green mass of alfalfa]. Vestnik Kurskoi gosudarstvennoi sel'skokhozyaistvennoi akademii [Bulletin of the Kursk State Agricultural Academy], 9, 45-48.

Ponomareva, M. A., Filina, M. P., \& Yakutenok, V. A. (2016). Tsirkulyatsionnoe techenie vysokovyazkoi nen'yutonovskoi zhidkosti v kanale odnoshnekovogo ekstrudera [The circulating flow of a high-viscosity non-Newtonian fluid in the channel of a single-screw extruder]. Vestnik Tomskogo gosudarstvennogo universiteta. Matematika $i$ mekhanika [Bulletin of Tomsk State University. Mathematics and Mechanics], 2, 97-107. https://doi. org/10.17223/19988621/40/10

Pristach, N. V., \& Pristach, L. N. (2017). Zhmykh rapsovyi v kormlenii skota [Rapeseed cake in cattle feeding]. Sel'skokhozyaistvennye vesti [Agricultural news], 1, 8-9.

Vasilenko, V. N., Frolova, L. N., Derkanosova, A. A., Mikhailova, N. A., Shchepkina, A. A., \& Davydov, A. M. (2018). Matematicheskoe obespechenie protsessa ekstrudirovaniya anomal'no-vyazkikh sred metodami planirovaniya eksperimenta [Mathematical support of the process of extruding anomalously viscous media by methods of experiment planning]. Vestnik Voronezhskogo gosudarstvennogo universiteta inzhenernykh tekhnologii [Bulletin of the Voronezh State University of Engineering Technologies], 80(3), 37-42. https://doi.org/10.20914/2310-1202-2018-3-37-42

Zaruba, A. S., Mustafaev, S. K., Kalienko, E. A., \& Andrzhaichak, A. A. (2015). Izuchenie kachestva l'nyanykh masla i zhmykha, poluchennykh po novoi tekhnologii dvukratnogo pressovaniya semyan l'na s ekstrudirovaniem [Study of the quality of flaxseed oil and cake obtained by the new technology of double pressing of flaxseeds with extrusion]. Elektronnyi setevoi politematicheskii zhurnal «Nauchnye trudy KubGTU» [Scientific works of the Kuban State Technological University], 2, 69-78.

Zubkova, T. M., \& Kolobov, A. N. (2015a). Ispol'zovanie programmnogo obespecheniya dlya opredeleniya i prognozirovaniya pokazatelei kachestva ekstrudirovannoi produktsii [Using software to determine and predict the quality indicators of extruded products]. Programmnye produkty i sistemy [Software products and systems], 3, 123-129. https://doi.org/10.15827/0236-235X.111.123-128

Zubkova, T. M., \& Kolobov, A. N. (2015b). Vliyanie ekstrudirovaniya semyan rapsa na kachestvo gotovoi produktsii [Influence of rapeseed extrusion on the quality of finished products]. Vestnik Rossiiskoi akademii sel'skokhozyaistvennykh nauk [Bulletin of the Russian Academy of Agricultural Sciences], 5, 11-14.

Zubkova, T. M., Ishakova, E. N., \& Tokareva, M. A. (2014). Razrabotka programmnogo obespecheniya vizualizatsii protsedury mnogomernoi optimizatsii funktsional'nykh pokazatelei tekhnologicheskogo protsessa [Development of software for visualization of the procedure for multidimensional optimization of functional indicators of the technological process]. Nauchno-tekhnicheskii vestnik informatsionnykh tekhnologii, mekhaniki $i$ optiki SPbGU ITMO [Scientific and Technical Bulletin of Information Technologies, Mechanics and Optics, St. Petersburg State University ITMO], 3, 156-162. 